\title{
Practicar a Dios con vigor y hablar de él con humildad
}

\author{
F. Javier Vitoria Cormenzana, \\ Instituto Diocesano de Teología y Pastoral, Bilbao, \\ Centro de Reflexión Teológica, San Salvador.
}

El cristianismo está llamado a ser una metáfora viviente de Jesús de Nazaret, practicando fielmente a Dios con el vigor de la compasión y la radicalidad de la misericordia solidaria. Solo después está invitado a balbucear humildemente palabras sobre Dios, que sean buena noticia para los pobres y para quienes sufren como consecuencia de la barbarie que se ha adueñado de nuestro mundo. Este trabajo pretende responder a esta doble fidelidad.

Formulo mi propuesta, "practicar a Dios con vigor y hablar de Él con humildad", en unos días en los que, a propósito de Irak, se ha hablado de Dios con altanería y se le ha practicado con el rigor de la guerra. Como pidiera M. Buber en el siglo pasado, en las actuales circunstancias los creyentes no debiéramos despreciar a quienes proscriben el nombre de Dios "porque se rebelan contra la injusticia y la sinverguiencería de aquellos que invocan a 'Dios' para justificarse". Precisamente esto es lo que ha venido haciendo G. Bush para legitimar la invasión a Irak. Sus pronunciamientos acerca del eje del bien, de la libertad duradera y de la defensa de los valores cristianos de occidente nos causan una enorme perplejidad a muchos de los ciudadanos y ciudadanas de la Europa secularizada. No ocurre así en Estados Unidos. La sociedad norteamericana, mayoritariamente creyente, proclama su fe en Dios incluso en la misma moneda nacional. $\mathrm{Y}$, además, muy frecuentemente la fusiona con otra fe, la del viejo sueño mesiánico de que es una nación elegida para realizar un plan divino sobre la humanidad. Estados Unidos está permanentemente en lucha contra los malos. El mundo es un inmenso campo de batalla en el que se enfrentan a la Bestia apocalíptica, cuya figura histórica hoy la representan el terrorismo internacional y el eje del mal de la misma manera que ayer lo hicieron el comunismo y Rusia. Semejante ideología política explica que el Dios de la guerra se haya convertido 
en un referente fundamental en las contiendas militares norteamericanas, desde Vietnam hasta nuestros días.

Para terminar esta introducción y antes de entrar en materia, aclararé que voy a utilizar el término "teología" en un sentido, al mismo tiempo, amplio y restringido. Amplio, porque con él me referiré a todo lenguaje creyente sobre Dios. A veces a los teólogos de oficio se nos olvida que quienes más hablan públicamente de Dios en nuestra sociedad son los obispos, los curas, las catequistas, los profesores de religión etc. $Y$ restringido, porque solamente me referiré a los lenguajes sobre el Dios de la tradición cristiana.

\section{1. ¿Cómo encontrar un camino para hablar de Dios?}

La verdad de cualquier lenguaje sobre Dios pertenece al orden del testimonio y es, por ello mismo, un lenguaje autoimplicativo (C. Geffré). Mencionar a Dios es, ante todo, un momento de la confesión narrativa (P. Ricoeur). J. B. Metz ha insistido en la estructura narrativa de la teología, en la necesidad de contar historias. Unicamente desde el caminar, según el Espíritu de Jesús de Nazaret, es posible pensar y anunciar el amor gratuito del Padre hacia cada persona humana (G. Gutiértez).

Los creyentes no tenemos otro motivo para hablar de Dios que nuestra fe en El. "Creemos y por eso hablamos" (2 Cor 4, 13), dirá S. Pablo. Se equivocan, por tanto, quienes piensan que la decisión de hablar sobre Dios y la determinación de la forma y manera de hacerlo se puede tomar de manera apriorística. Más ajustado a la realidad resulta que los creyentes nos encontramos a nosotros mismos hablando de Dios en nuestra vida interpersonal. Y siempre hay algo de autobiográfico en ese discurso. "El que quiera hablar de Dios ha de hablar necesariamente de sí mismo", escribió R. Bultmann. Como no comparto ni su individualismo, ni su pasmo existencial, he de añadir que la teología necesita hablar necesariamente de la sociedad si es que quiere hablar legítimamente de Dios. Vivimos tiempos de barbarie. J. Sobrino habla de "barbarie" como concepto fundamental para comprender y explicar la gravedad -cuantitativa y cualitativa, para la vida de millones de seres humanos- de los hechos que están ocurriendo en nuestro mundo'. En estas circunstancias hablar del Dios de vida siempre debería suponer un aguijón que nos sacara de nuestra insensibilidad ante la muerte de los pobres y nos pusiera en el camino de la compasión con las víctimas olvidadas e ignoradas de la barbarie.

Sin embargo, hablar de Dios nunca ha sido tarea fácil. La teologła siempre ha reconocido, al menos teóricamente, la necesidad de tomar precauciones para hacerlo. Sobre todo lenguaje acerca de Dios y sobre todas sus imágenes gravita

1. Terremoto, terrorismo, barbarie y utopía. El Salvador, Nueva York, Afganistán. Madrid 2002, pp. $171-173$ 
una tendencia idolátrica tan poderosa, que se ha podido decir que "un Dios del que se habla es ya un idolo"'. Sin embargo el silencio absoluto sobre Dios no es la manera más adecuada de resolver las dificultades. Si elimináramos todas las imágenes y los lenguajes sobre Dios, entonces correríamos el riesgo de exponer el reconocimiento de Dios a la pura irracionalidad. Necesitamos, eso sí, purificar las representaciones de Dios. Cuando hablamos de Dios con palabras, conceptos e imágenes condicionadas por nuestra experiencia y mi situación cultural, lo hacemos con voluntad de referimos a Alguien Incondicionado, con la conciencia de que no hacemos más que indicar, sugerir, apuntar hacia Aquel que es estrictamente incognoscible e inexpresable en sí mismo, y que sólo es vislumbrado, postulado, necesitado y exigido para que todo lo que constituye el mundo de mi experiencia no sea algo sin base, sin razón, sin valor, sin inteligibilidad ni coherencia. Pero todos hemos de ser muy conscientes de que sólo Dios puede hablar adecuadamente de Dios ${ }^{3}$.

En ese sentido, comparto plenamente la conclusión con la que J. A. Marina, apoyándose en J. B. Metz y J. Moltmann, cierra su dictamen sobre Dios: "Me parece observar un lento esfuerzo de las religiones para recuperar su pureza inicial, liberarse de basura histórica, y convertirse en religiones de segunda generación, es decir, en religiones éticas, más preocupadas por la teopraxia que por la teología, más preocupadas por divinizar la realidad que por evadirse divinamente de ella"4.

Sin embargo, en la Iglesia "corren tiempos de cruzada", en el asunto del lenguaje público sobre Dios. Quienes en este contexto hemos recordado que la prisa tampoco es buena consejera a la hora de nombrar a Dios, solemos caer bajo la sospecha de tibieza confesante. Y no siempre es así.

Entre nosotros se elaboran discursos sobre Dios, que siguen sin tener en cuenta el consejo de L. Wittgenstein, que nos mandó guardar silencio de aquello sobre lo que no se puede hablar; y, por otra parte, esos discursos parecen ser mecanismos de defensa ante una palabra, "Dios", que nos fuerza, nos irrita y nos perturba en demasía la tranquilidad de una existencia que quiere tener la paz de lo supervisable y manipulable. Pero también abundan sigilos que son pudorosos, sobrecogidos por "el mundanal Silencio" (R. Panikkar), y, por otra parte, publicidades rimbombantes y temerarias, hijas de la arrogancia crédula o de la ignorancia supersticiosa.

Quien se haya atrevido con semejante empresa habrá tenido que cargar con el gran problema de la religión y de los lenguajes sobre Dios. En el camino

2. R. Panikkar, Dios en las religiones, en V Congreso de Teología. Dios de vida, Idolos de muerte, Misión Abierta 5/6 (1985), p. 91.

3. Véase J. Vives, "Si oyerais su Voz..." Santander. 1988, p. 15.

4. Dictamen sobre Dios, Barcelona, 2001, pp. 227-228. 
abierto para nombrar a la "Tiniebla luminosa" (Gregorio de Nisa), incluso habrá sentido el vértigo del ateísmo; y frecuentemente, a pesar de las caulelas hermenéuticas que haya adoptado, le habrá resultado, en la práctica, imposible no ir a parar a los bordes de los precipicios de la blasfemia y la herejía.

\subsection{El problema de nuestra generación}

En los últimos cincuenta años, hemos recorrido el camino de la afirmación de Dios, primero, en la incómoda compañía de "los maestros de la sospecha" -L. Feuerbach, K. Marx, F. Nietzsche y S. Freud-, que nos acotaban el terreno. El oficio de la supervivencia lo aprendimos doliéndonos de sus "mordeduras", sin renunciar a la ruta marcada, a pesar de las heridas y de las bajas.

El conocimiento de que la palabra Dios llevaba sobre sí las huellas de la sangre y de la muerte de una guerra fratricida casi nos puso de bruces. Somos hijos o herederos de una generación que, como dijera Martín Buber, había matado y se había dejado matar por esta palabra. También nos hemos visto ante la apremiante necesidad de mostrar que no hablábamos de un Dios del desorden, establecido enfrentado a las libertades democráticas o de un Dios de ricos y burgueses, en detrimento de las mayorías populares empobrecidas. Por eso me resulta sumamente sorprendente que puedan hacerse balances del proceso de modernización de la teología española, o de cualquier otra teología regional, sin indagar si esa transformación se vio interrumpida, y en qué medida, por la memoria de los vencidos y perdedores de la moderna historia civil.

Tras la clausura del Vaticano II, tuvimos que afrontar, (ipor cierto! con muy escasos recursos teóricos), el anuncio de "la muerte de Dios" y ofrecer resistencia a la seductora proclama de que Dios era tan sólo "una manera poética, imaginativa de hablar acerca del hombre, sin la cual la vida en la ciudad secular quedaba tristemente empobrecida" (Van Buren).

El camino recorrido, sin haber dejado resueltas todas estas cuestiones, ha purificado nuestras pretensiones y hoy buscamos un lenguaje sobre Dios más simbólico y más próximo a la experiencia religiosa y al testimonio. Pero en los primeros compases del siglo XXI, nos enfrentamos con nuevas urgencias y desaf́os. Me limitaré a señalar tres de ellos.

En primer lugar, en el siglo pasado, el movimiento de las mujeres ha imumpido en la historia pública del mundo y ha tomado la palabra. También en las iglesias cristianas. En las últimas décadas, las mujeres creyentes han puesto al descubierto la exclusión generalizada y, sensacionalmente, efectiva de la mujer del ámbito de la formación del lenguaje sobre Dios. De manera gradual o de improviso, pacíficamente o irritadas, con entusiasmo o con angustia, tranquilamente o gritando, miles de mujeres y algunos hombres están ya de vuelta del restrictivo legado de la exclusividad del lenguaje sobre Dios. Las teólogas femi- 
nistas exigen carta de naturaleza para un nuevo lenguaje sobre Dios, desde el ámbito de su propia experiencia, que genere condiciones para la creación de una comunidad, caracterizada por relaciones de reciprocidad, de amor y de justicias. Incluso alguna de ellas considera necesario, teológicamente, desestabilizar de forma visible nuestra manera de pensar y hablar de Dios y propone con este fin un cambio en la forma de escribir su nombre: " $D * * s$ ".

La producción teológica de las mujeres me parece una novedosa, enriquecedora e inquietante (para los varones) aportación al esfuerzo por dar creativamente "nombre aproximado a Dios", en los nuevos contextos socioculturales. Aquí sólo quisiera dejar constancia de que este esfuerzo arranca de la propia experiencia de las mujeres, sin necesidad de recurrir a añadiduras y calificativos tan del gusto del lenguaje patriarcal eclesiástico. Sus vidas, sus luchas emancipadoras, sus deberes en la vida cotidiana, su amor a sí mismas, a otras mujeres y a los hombres de manera no subordinada, etc., constituyen una auténtica metáfora de Dios y dan origen a experiencias de El bajo nuevas condiciones.

El resultado no es ni la simple sustitución de un lenguaje teológico masculino excluyente por otro incluyente (por ejemplo, la reiteración de "los/las", la negativa a utilizar el término "hombre" para referirse a la especie humana y el recurso absolutamente heterodoxo a la @ en los plurales incluyentes, etc.), ni la feminización de las imágenes de Dios (padre/madre), en un contexto de lenguaje patriarcal y androcéntrico sobre Dios, ni el descubrimiento de la existencia de lo femenino en Dios (el Espíritu Santo). Todos estos esfuerzos dejan sin corregir el símbolo total de Dios, y sus opciones metodológicas ponen de manifiesto que no escuchan las propias autodefiniciones de las mujeres, sino que desartollan un punto de vista unilateral de "lo femenino".

Las teólogas feministas señalan constantemente que los símbolos religiosos femeninos de lo divino están infradesarrollados y son periféricos, y que su importancia (si es que se le concede alguna) es secundaria, en el lenguaje cristiano y en la praxis que éste configura. Más aún, la forma tradicional de hablar de Dios ha sido humanamente opresiva y religiosamente idolátrica. No sólo ha utilizado una imaginería y un lenguaje exclusivamente masculino, sino que, además, ha tenido un efecto destruclivo en la imagen espiritual que las mujeres tienen de sí y ha pervertido las relaciones de éstas con los cristianos varones y Dios. La plena realidad de las mujeres, igual que la de los hombres, ha de entrar en la simbolización de Dios, junto con símbolos procedentes del mundo natural, si quiere "romperse la fijación idolátrica sobre una sola imagen y ponerse de

5. Véase E. A. Johnson, La que es. El misterio de Dios en el discurso teológico feminisra, Barcelona, 2002, pp. 17-21.

6. Véase E. Schüsssler Fiorenza, Cristologia feminista critica. Jesús Hijo de Miriam, Profesa de la Sabiduría, Madrid, 2000, p 16. 
manifiesto para nuestro tiempo la verdad del misterio de Dios, juntamente con la liberación de todos los seres humanos y de la tierra entera". Si el evangelio del Dios de vida ha de hablar, en el siglo XXI, el análisis de las teólogas feministas debe ser tomado en serio y la cuestión de la experiencia como fuente de conocimiento ha de ser examinada con atención por todas las teologías?.

En segundo lugar, la muerte del Dios "explicación" reclama el clima de la gratuidad para su anuncio y el abandono del de la necesidad y de la importancia. ¿De qué modo hablaremos de Dios para que los hombres y las mujeres de hoy lo encuentren primariamente no en la dialéctica de las necesidades y de las indigencias, sino en la plenitud de su ser y de su vida? ¿Cómo ha de ser nuestro lenguaje para que el hombre "despierte como de un sueño, encontrándose en Dios y cayendo en la cuenta de que en su ateísmo no ha hecho sino estar en Dios"?"?

Las nuevas condiciones de experiencia permiten el acceso a un Dios gratuito, puro don, que deja de ser experimentado como explicación última de nuestras construcciones racionales, como deus ex machina, que responde a las necesidades de sentido y resuelve los problemas humanos o como coarlada para evadirse de los conflictos históricos.

Nos encontramos en unas circunstancias históricas que constituyen una ocasión inmejorable para que Dios irnumpa no como especulación, sino como Dios sin más. Vivimos un tiempo de gracia (kairós), en el cual se nos invita a realizar un esfuerzo honesto $-y$ a veces desesperado- para salir de nuevo al encuentro del Dios, que viene como tal Dios. Dios vuelve como promesa del futuro y revela que ningún acontecimiento de la historia de la salvación, incluso la resurección de Jesús, puede agotarla. Toda manifestación divina será más anticipación y manifestación progresiva de un porvenir siempre inédito hasta el fĩn de la historia que una epifanía de una presencia inmutable y eterna de Dios.

Dios retorna para desenmascarar las pretensiones de la modema racionalidad y exigirle que renuncie a sus ambiciones especulativas, encaminadas a controlar la realidad divina. Dios vuelve criticando los absolutos históricos que fabricamos los seres humanos y reclamando solidaridad y justicia para sus víctimas. Vuelve un Dios débil, que no descarga de la responsabilidad y protagonismo humano, sino que los refuerza, pues, como E. Hillesum ${ }^{9}$ escribe desde Auschwitz, "seré yo quien tenga que ayudar a Dios".

7. Véase E. Wainwright, Nuevo arrojo de la imaginación religiosa: “'Dios' en la teologia Seminista", Concilium 209 (2001), pp. 113-115

8. Véase X. Zubiri, El hombre y Dios, 'Madrid, 1985, p. 344.

9. Estas palabras se encuentran en los diarios conservados de esta joven judía holandesa, que se presentó voluntaria, en 1942, en el campo de concentración de Westerbork, para compartir el destino de su pueblo y ayudar a los prisioneros. En 1943 murió en las cámaras de Auschwitz. 
Seguramente, muchos compartimos el sentimiento de que estamos solos. pero abiertos a un Dios, que nunca llega en definitiva (esperando a Godot, con Samuel Beckett), aunque lo necesitamos más que nunca. El paso del tiempo nos ha erosionado creencias y vivencias. Cada vez creemos en menos cosas, tanto personal como socio-culturalmente ${ }^{10}$. Pero quizás hoy esternos en mejores condiciones que nunca para salir gratuitamente al encuentro de Aquel que, trascendiendo de modo infinito al mundo, es también el corazón y el seno del mundo en el que "vivimos, nos movemos y existimos" (Hech 17, 28). Y quizás también nos encontremos con una oportunidad histórica de oro o de gracia del Señor, por expresarlo en lenguaje cristiano, para comprometernos de manera libre con aquello que creemos y da sentido a nuestras vidas.

En tercer lugar y sobre todo, la empatía con el inmenso sufrimiento humano, producido y acumulado en este tiempo, está desplazando la cuestión de la identidad de Dios hacia la de su localización y plantea la más inquietante de las cuestiones sobre Dios: ¿cómo hablar de Dios desde el sufrimiento del inocente? (G. Gutiérrez) o ¿cómo hacerlo siendo sensibles a la teodicea? (J. B. Metz).

La teología necesita del concurso de "una fe humedecida por las lágrimas y enrojecida por la sangre" de los pobres. Bajo su inspiración va más hacia (los de) abajo y apuesta decididamente, como Job, por arrancar "desde el 'basurero" (cfr. 2, 10 la mazbaleh) de la ciudad para encontrar un lenguaje apropiado acerca de Dios"'."

Así lo ha intentado la teología contemporánea más relevante, tratando de responder a inquietantes preguntas: ¿cómo hablar de Dios después de Auschwitz? o ¿cómo hablar de Dios desde la pobreza y el sufrimiento del inocente? A lo largo del siglo XX todos los intentos de respuesta se han visto interrumpidos permanentemente. Los sufrimientos de las víctimas de un sinfín de nuevos "holocaustos", como Hiroshima, Vietnam, Camboya, Biafra, El Salvador, Ayacucho, Bosnia-Herzegovina, Etiopía, Palestina, Afganistán, Irak, etc., siguen reclamando que pongamos límite a tantas "palabras de aire" como pronunciamos, y que nos convierten en consoladores tan funestos como los amigos de Job (Job 16, 1-2). Necesitamos testigos de los nuevos holocaustos que atestigüen, como E. Hillesum en Auschwitz, "que Dios estaba vivo incluso en un tiempo como el nuestro".

Entre los múltiples desafíos que todo lenguaje religioso tiene ante sí, ninguno como el de atreverse a hablar de Dios desde "los basureros" de la aldea global. ¿A qué Dios aludimos, cuando los vecinos de la aldea global, que disfrutamos de los beneficios de un modelo de vida, sostenido por un sistema econó-

10. Véase J. A. Estrada, Imágenes de Dios, Madrid, 2003, pp. 306-307.

11. Véase G. Gutiérrez, Hablar de Dios desde el sufrimiento del inocente, Salamanca, 1986, pp. 53-56. 
mico de "destrucción masiva", protegido por un ordenamiento jurídico internacional claramente instaurado desde "la ley del embudo" (la parte estrecha para los pobres, la ancha para los ricos) y defendido por una sofisticada e infermal maquinaria militar, nos atrevemos a pronunciar su nombre? ¿Cómo evocamos la patemidad/maternidad de Dios -que Jesús nos reveló y el Espíritu nos hace invocar desde nuestro interior ( $c f r$. Gal 4,6 )- en un mundo en el que un número multimillonario y creciente de sus hijos e hijas viven hacinados en "los basureros" que hay repartidos por toda la geografla mundial? ¿Podremos evitar el uso vano del nombre de Dios, sin ver, ni compartir el atroz sufrimiento de los pobres (cfr. Job 2, 13)? ¿Cómo evangelizaremos a Dios mientras millones de personas humanas resultan superfluas para la convivencia?

Son interrogantes que no debiéramos echar en saco roto, a pesar de que nos desazonen. Su olvido convierte en cínico y blasfemo todo intento de nombrar a Dios. Tenerlos presentes nos desplaza del terreno de nuestros discursos al de nuestras prácticas. Desde hace tiempo estoy persuadido de que tanto histórica como escatológicamente "extra pauperes nulla salus". Ni hay salida a la situación terminal de la aldea sin contar con los pobres, ni haremos nuestra la salvación del Dios de Vida sin hacernos cargo, cargar y encargarnos de la historia humana como "ekumene de sufrimiento" (J. B. Metz). A los pobres debiéramos aplicarles extensiva y analógicamente aquellas mismas palabras de la Escritura con las que el Evangelio se refirió a Jesús de Nazaret: "la piedra que desecharon los arquitectos es ahora la piedra angular" (Mt 21, 42). Quienes desde la opción por los pobres intentamos, con temor y temblor, hablar de Dios habremos de estar dispuestos a pagar un doble precio: la pérdida de plausibilidad social.

Un texto muy conocido de G. Gutiérrez nos servirá de guía para responder a estas cuestiones:

En la perspectiva de la teología de la liberación se afirma que a Dios se le contempla y se pone en práctica su designio sobre la historia, y sólo después se le piensa. Lo que queremos decir con esta expresión es que la veneración de Dios y la puesta en obra de su voluntad son la condición necesaria para una reflexión sobre él. Sólo desde el terreno de la mística y de la práctica es posible elaborar un discurso auténtico y respetuoso acerca de Dios. En la práctica, concretamente en el gesto hacia el prójimo, especialmente hacia el pobre, encontramos al Señor, pero al mismo tiempo este encuentro hace más profunda y auténtica nuestra solidaridad con el pobre. Contemplación y compromiso histórico son dimensiones ineludibles e interrelacionadas de la existencia cristiana. El misterio se revela en la contemplación y en la solidaridad con los pobres: eso es lo que llamamos el acto primero, la vida cristiana; sólo después esa vida puede inspirar un razonamiento, el acto segundo. 
Contemplar y practicar constituyen juntos, en cierto modo, el momento de silencio ante Dios. El discurso teologico significa un hablar sobre Dios. Callar es la condición del encuentro amoroso -oración y compromiso- con Dios. La experiencia de la insuficiencia de las palabras para expresar lo que vivimos con profundidad hará nuestro lenguaje más rico y más modesto. La teología es un hablar enriquecido por un callar.

La reflexión sobre el misterio de Dios sólo puede hacerse desde el seguimiento de Jesús. Unicamente desde el caminar según el Espíritu es posible pensar y anunciar el amor gratuito del Padre hacia cada persona humana'.

\subsection{Elementos fundamentales del acceso a Dios}

\subsubsection{La singularidad del acceso cristiano al misterio de Dios}

En los últimos años se nos ha hecho muy familiar la conocida parábola budista y oriental del elefante rodeado por cinco ciegos como ilustración de que las religiones "locamos" y señalamos lo Ultimo, pero sólo podemos hablar de "lo penúltimo" de Dios. Recordémosla brevemente. Uno de los ciegos, locando una de sus patas, creía estar ante la columna de un templo; otro, tomando su cola. creía tener una escoba en las manos; a otro, palpando su vientre. le parecía estar bajo una gran roca; otro, dando con la trompa, se asustaba creyendo que tocaba una gran serpiente; el último, palpando sus colmillos, pensaba en la rama de un árbol. Y se ponían a discutir entre ellos sobre la certeza de su percepción y la infalibilidad de su interpretación.

Esta parábola tiene una triple virtualidad:

En primer lugar, remite al carácter analógico del conocimiento de Dios: las distintas identificaciones, sin ser descabelladas, son siempre del todo insuficientes. La teología clásica ya decía que la analogía sobre el conocimiento de Dios significa que la desemejanza es mucho mayor que la semejanza.

En segundo lugar, muestra el carácter condicionado de toda interpretación: reconocemos la realidad del misterio de Dios, a partir del conocimiento que tenemos de otras cosas, haciendo que toda percepción esté condicionada por las experiencias previas y por los cánones interpretativos, que nos proporcionan nuestras propias referencias.

En tercer lugar, señala que la realidad total es más, mucho más, que la prolongación o dilatación de una de sus partes. No se trata de relativizar la verdad de cada religión, sino de creer que hay una Verdad más alta, nunca abarcable por nuestras verdades parciales ${ }^{13}$.

12. G. Gutiérrez, "Un lenguaje sobre Dios", Concilium 191 (1984), p. 55.

13. Véase J. Melloni, Los ciegos y el elefante. El diálogo interreligioso, Barcelona, 2000. pp. 21-22. 
Hemos de reconocer que el cristianismo, y el catolicismo en particular, han caído frecuente en la lentación de creerse, en virtud de la revelación sobrenalural, en posesión de una visión global del elefante. Las consecuencias históricas de este orgullo religioso han sido extremadamente trágicas. Sobre todo para "los otros colegas ciegos", que tenían menos poder que él. Sea, pues, bienvenida la toma de conciencia de que también el cristianismo es "ciego". Su identificación del misterio es del todo insuficiente y su propio acceso al misterio de Dios es de carácter condicionado, relativo y parcial. La cura de humildad que esto supone no sólo puede favorecer la paz mundial, sino situamos en condiciones más favorables para acceder al misterio. El misterio de Dios es siempre inabarcable para el ser humano. También para Jesús el Padre fue misterio. Y cuando los cristianos decimos audazmente que creemos en Dios, porque El se ha revelado, no queremos decir que Dios nos haya dado algún cursillo de teología o se haya dejado retratar por algún teólogo intrépido. Mucho más modestamente confesamos: que Dios actúa en la historia en favor de los seres humanos y que, en ese actuar, revela algo de El, y que esa actuación divina tiene su centro y su cumbre en Jesús de Nazaret.

Dios se revela y acontece en la historia de aquel hombre de Galilea y en la novedad de "su ser-desde-Dios-y-para-los demás". El cristianismo vive de su memoria subyugante y subversiva. El mantenimiento de una praxis semejante a la suya, como ámbito propio de acceso a la experiencia de Dios, es una cuestión de vida o muerte para la tradición cristiana. Sus verdades de fe, su doctrina y su talante moral se quedan sin fundamento último, si se quieren mantener al margen de una experiencia de Dios como la que se hizo posible en y por Jesús de Nazaret. El cristianismo de forma audaz propondrá una "analogía de la praxis", es decir, la analogía del amor o la analogía del dolor compartido, como vía de acceso a Dios, "la cual, por supuesto, sigue dejando a Dios como semper maior y el Misterio indecible, pero nos indica por dónde ese Misterio ha querido acercarse a nosotros y hacemos atisbar una chispa de Su Luz"14.

\subsubsection{El seguimiento de Jesús, categoría noética}

El camino cristiano de acceso a Dios, a quien denominamos Padre, misterio de amor o misterio de liberación, ha de ser primordialmente práctico e implicativo. Sólo podemos llegar a El a través del compromiso operativo con la fraternidad, del camino del amor o de la praxis de liberación. Todas estas vías prácticas de acceso a Dios se concentran en un término central del Nuevo Testamento: el seguimiento. Esta categoría, durante mucho tiempo, ha sido acaparada por la vida religiosa consagrada, y desplazada al campo de la espiritualidad y de la piedad. Hoy ha sido recuperada, en gran medida, como concepto teológico,

14. Véase J. I. González Faus, "Mística del éxtasis y mística de la misericordia", en $E l$ factor cristiano, Estella (Navara) 1994, pp. 107-108. 
pues se considera que el seguimiento de Jesús es, precisamente, la puerta genuina de acceso a Dios para quienes creemos en él como la manifestación definitiva de Dios.

Algunos teólogos, tanto europeos como latinoamericanos, así lo han reivindicado expresamente: "Sólo siguiendo a Cristo saben los cristianos a quién se han confiado y quién los salva" (J. B. Metz). "El acceso a Dios sólo es posible en una praxis liberadora según el seguimiento de Jesús" (J. Sobrino).

"Ir a Dios", hacer experiencia de Dios en Jesucristo, "verlo" y encontrase con El en el rostro del resucitado reclama la identilicación práctica con la praxis histórica de Jesús. El seguimiento es la puerta cristiana de acceso a Dios, el paradigma desde donde los cristianos y las cristianas concretan su existencia espiritual. En toda circunstancia histórica, el espíritu del resucitado suscita hombres y mujeres capaces de recrear históricamente una experiencia teologal como la de Jesús, que les permita invocar a Dios como Abba (cfr. Gal 4, 6-7; Rom 8, 15-17) y poner en práctica esa paternidad divina, por medio de una misión mesiánica, en favor de los pobres. De este modo peculiar, los discípulos y las discípulas se transcienden a sí mismos hasta alcanzar las posibilidades últimas de su vida, descubren el más profundo significado de la existencia humana y se ven implicados en el compromiso de hacerlo realidad.

\subsubsection{Expectativa del reino y la experiencia de Dios}

El seguimiento de Jesús está ligado no solamente a la capacidad contagiosa que irradia su seductora personalidad, sino también a la sintonía y afinidad con los anhelos y exigencias de libertad, fratemidad y vida en plenitud que alentaba su utopía del reino. El interés mesiánico resultó decisivo en su "conocimiento" de Dios. Y nosotros no podemos prescindir de él, en aras de un cristianismo sin creencias, más plausible culturalmente, o de un cristianismo sin expectativa utópica, menos proclive a servir de refuerzo religioso a las ensoñaciones totalitarias de los mesianismos intrahistóricos. Si lo hacemos, nos habremos quedado sin "el guía" del conocimiento de Dios, que nos comunicó Jesús.

Efectivamente, la experiencia teologal de Jesús se realiza en el marco de una experiencia más global: la imupción del reino de Dios como acción liberadora y escatológica de Dios, dirigida de modo preferencial a los pobres, y desde ellos, a todo Israel. Las viejas esperanzas del pueblo de Israel estaban a punto de verificarse, y el reino de Dios imumpía como una buena noticia. La causa de la vida de Jesús, su pasión creyente, la ha resumido sumarialmente el evangelista Marcos: "Se ha cumplido el plazo, el reino de Dios está cerca. Arrepiéntanse y crean en la buena noticia" $(1,15)$.

Los discursos de Jesús sobre el reino de Dios no son fruto de una teoría asumida, sino de una experiencia vivida. Y toda la historia de Jesús (su compor- 
tamiento, su mundo de valores, sus palabras, etc.) sólo se explica desde aquello que constituye su más profunda verdad: vivir seducido por la experiencia del reino de Dios y del Dios del reino. Su experiencia de Dios forma parte inseparable de su experiencia del reino. $Y$ así se hace verdad en su vida aquello que más tarde recogerá el evangelista: "busquen primero el reino de Dios y su justicia, y todo lo demás se les dará por añadidura” (MI 6, 33). También la experiencia de Dios.

Jesús vive su fe en Dios, en el interior de su praxis histórica, en favor del reino. Por una parte, la experiencia teologal de Jesús se despliega en el empeño por hacer concreta e histórica la salvación escatológica. Jesús no sólo anuncia el reino, sino que lo hace real históricainente. Por otra, en este esfuerzo por hacer la salvación de Dios, Jesús va percibiendo quién es el Dios de la salvación. Y de este modo, su experiencia teologal (la seducción del Dios del reino) y su tarea liberadora (la pasión por construir el reino de Dios) se alimentan mutuamente. Por ello, únicamente sobre la base de la acción liberadora de Jesús es posible hablar de la originalidad de su relación con Dios: lo singular en él no es que invoque a Dios como Padre, sino que lo invoque por este nombre sobre la base de acciones de liberación, que cuestionan la autoridad del Dios de Israel.

En nombre de ese Dios se sienta Jesús a las mesas prohibidas, acoge a los pequeños y pobres, cura a paralíticos y ciegos aunque sea sábado, toca al leproso impuro que se atreve a acercarse a él, elogia al samaritano que iba de camino... Concede el primer puesto a aquellos y aquellas que en la sociedad de su tiempo no tenían puesto alguno. El amor de Dios le hace soberanamente libre y le llama a liberar a todos los que se le acercan: "El Espíritu del Señor está sobre mí... El me ha enviado para que dé la Buena Noticia a los pobres, para anunciar la libertad a los cautivos y dar la vista a los ciegos, para liberar a los oprimidos, para proclamar el año de gracia del Señor" (Lc 4, 18-19). Al contrario de lo que entonces se creía, Dios no escribe en el centro de la página, sino en sus márgenes. Jesús sabe cuál es la mano de Dios y sabe reconocerla y nos enseña a descubrirla's.

Las autoridades de Israel perciben que el Dios transparentado por la praxis liberadora de Jesús colisiona de modo frontal con su imagen de Dios. El escándalo no lo produce tanto la expresión $A b b a$, utilizada por Jesús para invocar a Dios, por muy inusitada que sea su utilización, cuanto el contenido que esa praxis confiere a la patemidad de Dios. Y así, de la misma manera que no perciben la práclica liberadora de Jesús (curar en sábado, relativizar el templo, liberar a los pobres, etc.) como anticipo de la plenitud escatológica del reino de Dios, sino como una acción de perdición (como antirreino o reino de Belcebú). considerarán blasfema su pretensión de justificarla, apoyándose en la paternidad de su Dios. El escándalo y la crisis estallan y, en consecuencia, terminarán por

15. R. Luneau, Jesús, el hombre que "evangelizo" a Dios, Santander, 2000, pp. 166-167. 
crucilicar a Jesús, pretendiendo dar gloria al Dios verdadero y salvar al pueblo de la perdición (Jn 11, 45-54).

\subsubsection{Utopía humana y experiencia de Dios}

Sé que los tiempos que corren no son buenos para la utopía, en el mundo de la abundancia. En su nombre, visionarios de todo tipo han sembrado la historia de barbarie y terror, aunque "el pragmatismo" rampante que todo lo invade sea tan inhumano como las utopías de antaño y hogaño, capaces de convertir el mundo en un infiemo, en nombre del paraíso soñado. El acceso a una experiencia de Dios como la de Jesús reclama hombres y mujeres alentados por la expectativa de una utopía sin contenido definido, ni definitivo (visée la llama P. Ricoeur) y universalizable (hasta alcanzar a los muertos, como J. B. Metz ha insistido, en multitud de ocasiones), capaz de alimentar permanentemente una ética de la convicción que motiva, a su vez, una ética de la responsabilidad, y se deja acompañar, en todo momento, por la esperanza.

Si queremos compartir la experiencia religiosa de Jesús, en el interior de una sociedad como la nuestra, propensa a acceder a todas las realidades -también a la religión-, desde los parámetros de la cultura del espectáculo, habremos de superar las actitudes preferentemente receptivas, estéticas y meramente contemplativas que genera. Habremos de buscar revestimos del talante activo y movilizado de quienes son inspirados por los anhelos y requerimientos de algún acontecimiento futuro histórico y mundial de interés universal. Por ejemplo, el final del hambre en el mundo, el cese de las prácticas xenófobas y racistas, un desarrollo sostenible, la paz regional y mundial, la liberación de las minorías culturales y étnicas o el despliegue real de la tradición de los derechos humanos.

Lemas escatológicos como el de I. Ellacuní, revertir la historia, el de J. Sobrino, que la vida sea posible, el de E. Bloch, que el mundo llegue a ser un hogar para el hombre o el de los nuevos movimientos sociales alternativos, otro mundo es posible, concentran todos los deseos humanamente verdaderos y todos los anhelos movilizadores, que nos pueden poner en sintonía con la experiencia humana de Jesús de Nazaret. Las prácticas que habilitan para conservar fresca la memoria de los muertos y el recuerdo de sus causas vencidas, intensificar el compromiso con el presente y mantenerse en pie enfrentados a un futuro sin devaluaciones están suministrando un material experiencial imprescindible para hacer la experiencia religiosa del Padre que Jesús hizo.

\subsection{Los pobres, lugar teologal}

Los pobres constituyen el sacramento de Dios, en nuestra aldea global, su palabra-presencia más elocuente ("epifanía real", los dominará E. Dussel ${ }^{16}$ ), su

16. Véase "Dominación-liberación: un discurso ceológico distinto", Concilium 96 (1974), pp. 346-347. 
llamada inerme a interrumpir definitivamente la historia de la violencia y de la explotación del hombre por el hombre. La gloria que Dios ha otorgado al ser humano, la condición de imagen divina y de hijo suyo, se encuentra alienada y el mismo Dios de la gloria vive libremente en ellos, reclamando su liberación. En una palabra, "el pobre es lugar de Dios, lugar teofánico privilegiado" (V. Araya).

Participar del "privilegio hermenéutico" de los pobres", ya constatado por Jesús de Nazaret ( $c f r$. Mt 11,25), resulta sumamente necesario para nosotros. La experiencia de encuentro con este Dios no se alcanza a través de explicaciones de gurús o de maestros espirituales. Su vereda se adentra en "la experiencia universal de la noche oscura" para contemplar la realidad, desde el reverso de nuestras sociedades satisfechas, y ser alcanzado allí por la mirada purificadora de Dios, en los ojos de los pobres, y por su palabra salvadora, en el grito inarticulado de las víctimas. El encuentro cristiano con Dios pasa por la ruptura de la sacramentalidad (J. I. González Faus), propuesta por Mt 25, 31, texto que ha de entenderse antes en clave de revelación de la presencia de Dios en la historia que de exigencia ética.

El permanente "exilio" de Dios no encuentra otra posada terrena que no sea ese basurero donde se amontonan y ocultan los excedentes humanos de esta aldea global. En la medida en que al contemplar somos contemplados y al mirar nos dejamos mirar por el Dios de vida en los ojos femeninos de la pobreza, en los sin-vida de las víctimas de la guerra, en los negros como pozos de los viajeros de las pateras, en los perdidos de los niños famélicos, en los vidriosos de los prisioneros de la droga, en los mortalmente heridos de los enfermos del sida, en los sin esperanza de los parados de larga duración, en los desbordantes de soledad de los ancianos abandonados a su suerte, en los inquietantes de los indígenas de las culturas minorizadas o en los anhelantes de los refugiados de cualquier "país en llamas", etc., esa experiencia provoca la "infusión secreta,

17. La fómula el privilegio hermenéutico de los personas y de los grupos oprimidos ha sido acuñada por L. Cornie, "The Hermenutical Privilege of the Oppressed", en Proccedings of the Catholic Theological Sociery of America, 33 (1978), pp. 115-181. Citado por E. Schillebeeckx, "Universalité unique d'une figure religieuse historique nomme Jésus de Nazareth", Laval théologique et philosophique, 50, 2 (juin 1994), p. 281. D. Tracy considera "ambigua la afirmación de que los pobres tienen un "privilegio hermeneutico': que ellos son los 'privilegiados' para Dios, sí; que son aquellos cuya interpelación más necesidad tenemos de escuchar lodos los demás, sí (y un sí que reconoce la represión de esas interpelaciones en el pasado y en el presente). Que sólo esas interpelaciones son 'privilegiadas' porque son las únicas que deben ser oídas, clara y rotundamente no. Esta pretensión es más adecuada para la revolución cultural de Mao que para la conversación y los debates teológicos serios, libres, colectivos y no ideológicos", cfr. Pluralidad y ambigüedad. Hermenéutica, religión, esperanza, Madrid, 1997, p. 156, n. 56. 
pacífica y amorosa de Dios" e inflama el alma, en espíritu de amor. Los despojos humanos de la barbarie se perciben cargados con "el peso inmenso de la gloria etema" de Dios ( $c f r$. 2Cor 4, 16). Entre los pobres y la experiencia cristiana de Dios existe un "aire de familia". De esta afinidad nos ha hablado con rotundidad el testimonio neotestamentario de la revelación del Dios salvador. ¡El que tenga oídos para oír que oiga!

Los seguidores de Jesús se encuentran así instalados en el camino de "una mística de ojos abiertos" (J. B. Metz), fuente de conocimiento de la realidad y también de Dios. Entre los pobres y la experiencia cristiana de Dios existe un "aire de familia". De esta afinidad nos habla con toda claridad el testimonio neotestamentario de la revelación del Dios salvador. Jesús de Nazaret necesitó referirse a los pobres para dar razón de la impción del Dios del reino en la historia (cfr. Lc 4, 14-21). Desde entonces, la "movilidad hacia los de abajo" resulta dirección y cita obligadas para quienes han sido invitados por El a realizar su misma experiencia y a invocar con $\mathrm{El}$ al Dios del reino como Abba (cfr. Mt 11, 25). Los pobres se perciben cargados con "el peso inmenso de la gloria eterna" de Dios (cfr. 2Cor 4, 16).

\subsection{Conclusión: todo lenguaje sobre Dios es un acto segundo}

Quien quiera hablar de Dios cristiana o jesuánicamente habrá primero de practicar a Dios con vigor y fidelidad, como hizo Jesús. El cambio de residencia mental y social y la cohabitación con los pobres resulta referencia normativa para los cristianos de nuestras sociedades satisfechas que quieran acceder al encuentro con Dios, "el del llanto inconsolable". Compartir sus causas y sus sufrimientos permite ser copartícipes de su "privilegio hermenéutico", e identificar en ese "no sé qué que en los pobres queda balbuciendo" la gloria y los rumores del Dios siempre adveniente a la historia. Esta experiencia mística autentificará su discurso sobre Dios.

Cuando los teólogos pretendemos "balbucear un no sé qué" sobre Dios no debiéramos olvidar nunca que intentamos algo muy difícil, si no imposible: hablar sobre el misterio. Pero sobre todo, debiéramos tener presente que nuestra verdadera cruz no consiste en explicar lo inefable, sino en seguir históricamente, como todo discípulo, el camino de Jesús. Sólo entonces su "ciencia" sobre Dios destilará esa sabiduría de Dios, mucho más honda que toda ciencia, que se impregna en el seguimiento de Jesús, y de la que han sido expertos los santos y los profetas. En delinitiva, el teólogo se podrá atrever a pensar y a balbucear algo sobre el misterio de amor, porque antes ha tenido la tremenda osadía de creer y practicar el amor, según las claves de Jesús, es decir, se ha atrevido a "practicar a Dios". Y así, la experiencia de la insuficiencia de sus palabras para expresar lo que vive en profundidad, a pesar de su incapacidad, hará su lenguaje más rico y más actual. 
Quien vaya a hablar de Dios, en contemporaneidad con la barbarie de los nuevos campos de exterminio, debiera tener siempre presente aquella impertinencia de S. Kierkegaard: ¿Qué es un profesor de reología? Es uno que es profesor porque otro ha sido crucificalo. La menoria del crucificado pone al descubierto un Dios mucho más preocupado por cómo nos comportamos con las "cruces-móviles" de la historia, con los pueblos crucificados, en expresión de I. Ellacuría, que por cómo lo pensamos a El en la cruz. La eclesialidad del teólogo se juega más en la porfía por hacer posible una Iglesia trasparencia del Dios de los pobres que en la obsesión por defenderla de los ataques del secularismo y del laicismo. Si el té́logo no vive afectado por el sufrimiento y el destino histórico de los crucificados de su tiempo, ni su seguimiento será el de Jesús, ni su silencio oracional merecerí todavía el calificativo de cristiano, ni su teología será expresión temblorosa y balbuciente de la luerza y sabiduría de Dios ( $c f r$. 1Cor 1, 24).

Dicho todo lo cual y para evitar sospechas de rebajas en el pensamiento, añadiré que el teólogo seguirá radicalmente obligado a tomarse muy en serio todas las mediaciones de la teología. Y ello deberá exigirse al máximo a los teólogos. Pero en ese ejercicio teológico inspirado por la misericordia, el teólogo habrá aprendido que su trabajo es obra de la gracia del Dios de las misericordias.

\section{Eclipse de Dios y nube de testigos}

En este tiempo de "eclipse de Dios" (M. Buber), hemos tenido en nuestro entorno "una gran nube de testigos": Dietrich Bonhoeffer, Paul Schneider, Etty Hillesum, Karl Rahner, Teilhard de Chardin, Oscar Romero, Rutilio Grande, Ignacio Ellacuría y compañeros, Enrique Angelelli, Simone Weil, Teresa de Calcuta, el abbé Pierre, Juan XXIII, Pedro Arrupe, María Elena Moyano, Luis Espinal, José María Grant y compañeros, Ricardo Alberdi, Diamantino García, Leónidas Proaño, los maristas y las religiosas de Ruanda, tantas "madres de mayo" abandonadas y un sinfín de historias evangélicas anónimas "de gente feliz" (D. Aleixandre), ignoradas y menospreciadas por escribas y fariseos autosacralizados. "El mundo no era digno" de ellos y, sin embargo, Dios no se avergonzó de ellos, ni tuvo a menos el ser apellidado Dios suyo (cfr. Heb 11 , 16.38 - 12, 1). Sus historias - itan humanas!- nos han vuelto a narrar "la historia más bella de Dios". Sus vidas nos han evocado la imagen carnal de Dios, Jesús de Nazaret, porque reflejaban la gloria del Señor (cfr. 2Cor 3, 18).

Desde hace algunos años vengo repitiendo la fórmula historias intempestivas de solidaridad, rumores del Dios de vida. Con ella busco señalar algo que considero prioritario no sólo para la tarea evangelizadora en general, sino, en particular, para el anuncio explícito de Dios. 
Pretendo recuperar la clave de Jesús, en su manifestación pública, en la sinagoga de Nazaret: la profecía de Isaías sobre la definitiva intervención de Dios en la historia encuentra, en la práctica de Jesús, en favor de los pobres, un crédito, el de su cumplimiento, que ningún anuncio solemne es capaz de igualar ( $c f r$. Lc 4, 14-21). E igualmente, conservar la originalidad que la expresión Abba recibe del contexto de prácticas en favor de los pobres, desde el que Jesús de Nazaret invoca a Dios como Padre.

No debiéramos olvidar que nada silencia y excluye más la posibilidad de la existencia de un Dios de vida que el creciente, masivo, injusto e inhumano sufrimiento de los pobres del mundo. Para hacer más creíble y significativa cualquier palabra de la Iglesia sobre El, propongo privilegiar la tarea común de atreverse a transitar solidariamente. Sugiero dar la palabra a esas historias intempestivamente solidarias y fieles, que abren espacios a esa civilización del amor, tan reivindicada por Juan Pablo II, por donde corren los rumores del Dios de vida. El Dios de Jesús no podrá seguir vivo en nuestra historia más que del mismo modo que entró en ella: impulsado hacia adelante por el rumor de los que siguen a Jesús. Son los rumores que levantan sus seguidores lo que hace que el proceso de Jesús vuelva a comenzar en cada época. La seducción del amor de Dios "se hace contagio en la Iglesia, a través de la cadena de testigos encargados de anunciar el Evangelio y de invitar a la fe"l".

Cuando hablo de "historias intempestivas de solidaridad" me refiero a esas semblanzas humanas de cuño evangélico, empeñadas en inventar el mundo de nuevo, henchidas de esperanza en el futuro y de ironía hacia las pretensiones de "los alquimistas" del egoísmo ilustrado. Historias de hombres y mujeres, cuyas historias pretenden dar la palabra a los sin voz y ser salida real para una sed de justicia, que clama al cielo del Dios de vida.

Entre ellas hay algunas estelares. He recogido el nombre de los protagonistas de algunas de ellas: "mártires del reino de Dios y de la política de Dios" (L. Boff), santos laicos y pastores y santas doctoras de nuestro tiempo. Sus historias contemporáneas son las que mejor emiten ecos de aquel primigenio rumor sobre el Dios, que resucita a los muertos. Ellas no provocan ensordecedores "clamores de Dios", pero producen una frecuencia en la que se escucha el suave rumor del Dios, compañero fiel de los pobres. Funcionan como un colirio que dilata las pupilas de los ojos para ver (cfr. Ap 3,18 ) en la oscuridad un futuro siempre mayor, en el cual se vislumbra al Dios por venir. Esas historias, expresión de un amor humano preferencial por los pobres y por la justicia, amplían el espacio de credibilidad de la existencia del Dios de vida. Ellas, pretendiendo evitar que la creencia en una vida antes de la muerte se diluya en una añoranza inútil y en un anhelo estéril, consiguen que el empeño cristiano por nombrar e invocar a Dios

18. B. Sesboüé, Jesucristo, el único Mediador, T. II, Salamanca, 1993, p. 363. 
sea prolongación del de Jesús, y su carácter de buena noticia, homologable con el del Espíritu del reino de los pobres.

Otras muchas historias constituyen una tupida red de relatos humanos anónimos, protagonizados por mujeres y hombres corrientes, que se hacen presentes habitualmente en los escenarios de la solidaridad sin límites con el fin de explorar y explotar al máximo el rico filón de lo inédito viable de la utopía del reino. Son todas esas historias las que, cuando abandonan su carácter rigurosamente incógnito propio de lo privado, son percibidas como extraordinariamente internpestivas por los medios de comunicación social.

Todas ellas están protagonizadas por gentes de came y hueso. Al mismo tiempo justos y pecadores, militantes incansables de las grandes causas históricas y "enganchados" a pequeñas aficiones familiares, navegantes enriquecidos en el interminable viaje hacia Itaca y náufragos aferrados tercamente a los restos del "hundimiento de las utopías", en medio de la inmensidad del océano, resistentes a las inclemencias y vulnerables a la ternura, constantes en el bregar y cansados de la faena, centinelas del mañana y con los ojos cargados por el sueño de incontables noches de vigilia.

Sus itinerarios vitales poseen todos los rasgos identitarios de "las historias evangélicas de gente feliz" (D. Aleixandre), es decir, el aire inequívoco, el talante contagioso, el estilo inigualable del Evangelio de Jesús. Todos ellos son espirituales auténticos: mujeres y varones seducidos, movidos y consolados por el Espíritu de Jesús, que asumen sus opciones con su misma pasión. Viven historia adentro, buscando la ciudad futura y afincados "fuera del campamento", en el lugar donde los pobres cargan con "su oprobio" (cfr. Heb 13, 12) y su "necesaria" crucifixión (cfr. Jn 11, 50); circulan a "contrapelo" de este tiempo que ha "teologizado" el mercado total, decretado la imposibilidad de las utopías, entronizado culturalmente los valores del individualismo, la privatización y el goce compulsivo del presente, y proscrito toda ética con pasión (es decir, compasiva, y por ello mismo, no exenta de padecimientos). Paradójicamente, ese "desierto" es como un regazo en el que reciben luz, calor y compañía. Todos ellos han recibido la visita de Dios como exceso amoroso y como voz inquietante, como "madre que ama y crea la vida y como padre que llama y crea la historia"19.

\section{3. "No apresurar el nombre de Dios en vano"}

Si no quiere caer en la tentación de "apresurar el nombre de Dios en vano", el lenguaje sobre Dios necesita nutrirse de historias intempestivas de solidaridad, que acrediten y actualicen contemporáneamente la permanente estructura

19. Véase C. Domínguez Morano, "Místicos y profetas", Selecciones de Teología 165 (2003), p. 15. 
kenótica de la revelación y la salvación de Dios. Las historias solidarias, como la de Jesús, son capaces de levantar rumores sobre el Dios de vida. Ellas nos autorizan a quienes hablamos hoy de Dios -teólogos, predicadores, catequistas, profesores de religion, etc.-, mejor que las instituciones académicas, para hablar con veracidad de Dios "desde el basurero" (G. Gutiérrez), anunciar proféticamente que "Dios viaja en pateras" o proclamar metafóricamente que "Dios resucita en la periferia" (R. M. Grácio das Neves), justamente alll donde sus hijos e hijas más queridos son crucificados. La teología cristiana ha de ser fiel y dar cuenta de la imagen histórica de Dios (Jn 14, 9), vinculada parcial, solidaria e indivisiblemente a los crucificados de la historia.

En los años sesenta, la Iglesia se sintió interpelada por una pregunta acerca de su identidad: "Iglesia, ¿qué dices de ti misma?". Su respuesta práctica colectiva no ha sido suficientemente significativa. Hoy, la pregunta ha cambiado. El mundo le pregunta: "Dinos centinela, ¿qué ves en la noche?" ( $c f r$. Is 21,11 ).

El lenguaje eclesial sobre Dios necesita contar historias de solidaridad, que sean una terca y suave -"aguijón y ternura a la vez"- invitación a cambiar el modo de pensar y de vivir, una provocadora incitación a verificar con la propia vida la verdad de la realidad, que esas historias narran.

Hay en la Iglesia historias que ayudan a resolver de forma positiva la ambigüedad social de la religión y acreditan prácticamente el capital simbólico del mensaje cristiano para la construcción de un futuro más humano. Historias que actualizan biográficamente y refrescan el recuerdo de la tradición del buen samaritano, que ha comenzado a desdibujarse en la memoria colectiva de las nuevas generaciones y a perderse como referente cultural, que nos ayuda a definir y a darnos cuenta de las posibilidades que tiene la compasión, en nuestro mundo. Historias que humanizan el aire que respiramos y permiten al cristianismo poner de manera explícita o anónima a los hombres y mujeres de nuestro tiempo, "en el camino de la deiformación" (J. Sobrino).

Sin embargo, la Iglesia no podrá narrar sus historias de solidaridad intempestiva, si no es capaz primero de descubrirlas y ampararlas. Esto que parece tan sencillo puede resultar en extremo complicado. A veces, justamente, quienes cumplen la función de vigías (epískopoi), en la Iglesia, no son capaces de reconocer en ella el paso del Señor y no cumplen de modo adecuado con su oficio de comunicar la virtud de Dios a los creyentes para la salvación, por medio del ministerio de la palabra (cfr. LG 26).

Las proclamas sobre la existencia de Dios, autentificadas por una praxis solidaria, en favor de los desfavorecidos, como la de Jesús, con seguridad serán percibidas por muchos de nuestros conciudadanos satisfechos de las sociedades desarrolladas como malas noticias sobre Dios. Pero para quienes vivir sea no resignarse, quizás puedan encontrarse, a través de esa parcialidad solidaria, con 
la "presencia elusiva" (G. Amengual) y reconocer y ver allí la novedad de un Dios amor, solidaridad y don. Un Dios que paradojicamente se manifiesta como juicio definitivo de la historia y posibilidad trascendental agraciada, llamada liberadora y camino real de universalización humana. En la práctica solidaria y en el sacrificio por los seres humanos encontramos un contexto humano tangible dentro del cual se puede introducir en las sociedades secularizadas una noción de Dios relevante. El camino hacia el prójimo del evangelio (el pobre) posibilita el acceso a la experiencia de Dios. La palabra "Dios" adquiere, en esas historias de solidaridad, una inteligibilidad peculiar, llena de sentido, que otros que no la pronuncian pueden entender, aunque carezca de estricta fuerza probatoria racional y universal.

Los católicos hemos de invocar y hablar de Dios en nuestra sociedad secularizada, pero no de un modo precipitado. Buscar el momento y el contexto oportuno es una cuestión decisiva para no usar el nombre de Dios en vano. En un contexto social en el que la fe en Dios no haga a los cristianos más humanos que a los demás o "personas decentes", como sencillamente pide J. Sobrino, pronunciar pronto el nombre de Dios suele suscitar imágenes caducadas y contraproducentes.

\section{La dialéctica del lenguaje sobre Dios}

El acceso a Dios siempre es a tientas, y el discurso sobre El, balbuciente. El esfuerzo de hablar de Dios tiene su origen en la nostalgia que el hombre tiene de ver a Dios y de hacerse cargo del impulso creador que lo origina. "Muéstrame tu rostro, Señor" es la voz que resuena en ese deseo natural. La tentación religiosa, también la del teólogo, es hacerse cargo y neutralizar la presencia que lo provoca, a través de sus ideas, conceptos y representaciones, así como a través de sus méritos, esfuerzos y trabajos. La interpretación teológica debe ser siempre un modo de indagación notablemente precario. La teología y el teólogo que olviden su modesta condición correrán el riesgo de caer en el pecado de idolatría y de promover prácticas inhumanas.

Con su crítica a la autosuficiencia del logos moderno, la posmodernidad ha abierto una nueva posibilidad a la elaboración de un nuevo pensamiento sobre Dios, más fiel a la tradición judeocristiana. En la actualidad, el problema de Dios se ha convertido, por una parte, en la cuestión más gratuita y el camino de acceso a Dios, en la carrera más libre a elegir. En este contexto, Dios ha podido dejar de ser experimentado como "explicación" para ser captado como puro don $^{20}$.

La crisis del ingenuo optimismo acerca de las posibilidades ilimitadas del conocimiento racional está abriendo nuevas vías a la recuperación del sentido

20. Véase E. Schillebeeckx, Jesús en nuestra culıura, Salamanca, 1987, pp. 12-16. 
del Misterio ${ }^{21}$. Se percibe de manera nueva la cuestión de la inmanencia y la transcendencia de Dios, en el mundo. Se abre paso la idea de panenteísmo, tan querida para algunos pensadores idealistas, como Hegel y Whitehead, siguiendo la fórmula insuperable de san Agustín: "tú estabas dentro de mí, más interior que lo más íntimo mío y más elevado que lo más sumo mío"?2. Se consolida el discurso relacional sobre Dios al amparo de la consideración posımodema del carácter intrínsecamente relacional de toda la realidad, y muy en especial, de la realidad divina. El actual discurso sobre Dios pretende que Dios irrumpa en la historia no como especulación, sino como Dios sin más. La leología contemporánea es un esfuerzo honesto, y a veces desesperado, por lograr que Dios sea escuchado de nuevo como tal Dios, por desbancar el predominio del logos moderno para devolvérselo a Dios. Dios retoma en la teología contemporánea para desenmascarar las pretensiones de la modema racionalidad y erradicar al theos que sirvió de fundamento a la onto-theo-logia de la modemidad, a la vez que se dejaba domesticar por ella. Dios retorna para exigir que la modemidad renuncie a sus ambiciones especulativas. encaminadas a controlar la realidad divina, de modo que Dios vuelva a ser de nuevo Dios. Dios vuelve reclamando solidaridad y justicia para todas las víctimas del proyecto moderno ${ }^{23}$.

La crisis de la ontoteología ha abierto las puertas a una teología no metafísica, en sintonía con la revelación, que "se esforzará por expresar la primacía ontológica del futuro sobre el presente en el Ser divino. La eternidad no será ya una propiedad negativa: la ausencia de tiempo. Significará el poderío de Dios sobre el futuro. Si el futuro es el modo de ser más apropiado del Dios de la Biblia, entonces se comprende que escape a las objetivaciones del teísmo y que ningún acontecimiento de la historia de la salvación, incluso la resurrección de Cristo, puede agotar sus promesas [...] La verdad del discurso sobre Dios será más anticipación y manifestación progresiva de una realidad futura que adecuación respecto a una esencia inmutable. Y la historia no será tanto la epifanía sucesiva de la presencia eterna de Dios cuanto el cumplimiento progresivo de un porvenir siempre inédito, que no se desvelará sino al fin de la historia, pero que abre cada momento presente hacia el futuro" 24 .

Los aires culturales favorecen una experiencia de Dios más ajustada a la maqueta "kenótica" (anonadada) de su revelación. En este sentido tenemos ante nosotros la oportunidad histórica de "experienciar" a Dios de manera semejante

21. Véase J. Vives, De Heidegger a Vattimo. ¿Recuperación del sentido del Misterio?, en X. Quinzá Le6 y J. J. Alemany Briz (eds.), op. cit., pp. 67-76.

22. Confesiones, III, 6, 11, Obras de San Agustín, Tomo II, Madrid, 1951, pp. 160-161.

23. He seguido muy de cerca las reflexiones de D. Tracy, "El retomo de Dios en la teología contemporánea", Concilium 256 (1994), pp. 997-1009.

24. C. Geffré, "Sentido y contrasentido de una teología no metafísica", Concilium 76 (1972), p. 418. 
a como El ha hablado de sí mismo. Hoy, nuestro encuentro con Dios puede acontecer gracias al reconocimiento como suya de la "la voz de un silencio tenue" (D. Aleixandre) que, como a Elías, nos hace remontar nuestra fe deprimida y salir de "la cueva" de nuestra desilusión airada $(1 \operatorname{Re} 19,12)$.

Tanto la realidad del misterio divino como el tipo de conocimiento que le pertenece hacen inevitable que el discurso sobre Dios sea un lenguaje simb6lico. El misterio de Dios se indica, se evoca, se sugiere, se denota, se refiere, se implica y se postula, a través de una realidad lingüística, cargada con esa dialéctica del simbolismo, que revela y oculta al mismo tiempo. Al lenguaje religioso sobre Dios le pertenecen la analogía, la metáfora, la narración, el tropo, el antropomorfismo, etc. Podemos referimos al Dios trascendente inmanentemente o al Dios inmanente trascendentemente. Podemos y debemos hablar dialéclicamente de Dios. Veamos un ejercicio práctico de Hadewijch de Amberes, "una trovadora" de Dios:

Son sus violencias lo más dulce de Amor, su abismo insondable es su forma más bella, perderse en él es alcanzar la meta.

Tener hambre de él es alimentarse y deleitarse, la inquietud de amor es un estado seguro, su herida mayor, bálsamo soberano, languidecer por él es nuestro vigor, eclipsándose se revela, si hace sufrir, da salud, si se esconde, nos muestra sus secretos, es rehusándose como se entrega, no tiene rima ni razón y es poesía, cautivándonos nos libera, sus golpes más duros son el más dulce consuelo ¡qué privilegio si nos toma por entero!

Es cuando se va cuando está más cercano, su silencio más hondo es su canto más alto, su cólera peor, su mejor recompensa, su amenaza nos calma y su tristeza consuela todas las penas: no tener nada es su riqueza inagotable.

Pero del Amor se puede decir también que su seguridad nos lleva al naufragio, y su estado más sublime nos hunde hasta el fondo; 
su opulencia nos empobrece

y sus beneficios son nuestras desdichas;

sus consuelos nos agrandan las heridas;

su trato es a menudo mortal;

su alimento es hambre, su ciencia, extravío;

su escuela nos enseña a perdemos,

su amistad es cruel y violenta;

nos huye cuando nos es fiel, para manifestarse se esconde sin dejar rastro,

y sus dones nos despojan aún más.

Sus promesas son seductoras, su ornato nos desnuda, su verdad nos decepciona y su seguridad es mentira.

Este es el testimonio que yo misma y muchas otras podemos manifestar, quienes vimos del Amor las maravillas, y recibimos escarnio al creer poseer lo que para sí guardaba.

Desde que así jugó conmigo y aprendí a conocer sus modos, me comporto de manera muy distinta:

no me engañan ya ni promesas ni amenazas; yo le quiero tal cual es, y poco importa que sea dulce o cruel.

Cuando no se respetan las reglas de este juego dialéctico y se rompen, entonces, convertimos lo simbólico en diabólico y aparecen los ídolos. El ídolo absorbe lo divino en sí mismo, paraliza y cautiva la mirada, deteniéndola en él, e imponiendo su visibilidad. Así, impide que nuestra mirada lo atraviese y se eleve hacia la realidad invisible, que él pretende representar. El icono o lo icónico, por el contrario, trata de hacer visible lo invisible como tal, se retira para que lo invisible surja sin quedar paralizado en lo visible. Por tanto, permite que lo visible no cese de remitir a otro que él mismo, sin que, a pesar de ello, este otro se reproduzca jamás en él. El mismo concepto puede ser idolátrico si no renuncia a comprender lo incomprensible. Pero puede ser icónico, cuando deja subsistir la profundidad infinita de su intención; porque, entonces, mantiene la justa distancia entre lo visible y lo invisible; de suerte que vale como icono el concepto o conjunto de conceptos, que refuerza tanto la distinción de lo visible 
y lo invisible como su unión. Y, por lo mismo, tanto más intensifica la una cuanto más subraya la otra ${ }^{2 s}$.

\section{Conclusión}

Las consecuencias de todo ello para el discurso sobre Dios son evidentes.

Primera. Nigún lenguaje acerca de Dios debiera olvidar nunca que es un hablar de Dios ante Dios y hacia Dios. Más concretamente, que es un lenguaje testimonial, que se inmiscuye en la ambigüedad de la historia para esclarecerla, mostrándose como palabra crítica y útil, como palabra consoladora y gozosa ${ }^{26}$. También los teólogos tomamos la palabra para predicar el nombre Dios como evangelio en este mundo y no para especular sobre su significado universal. En este sentido nuestra contribución a la crítica de los nombres e imágenes al uso (y abuso) de Dios puede resultar decisiva. $E$ imprescindible nuestra aportación a la señalización de cuáles son los menos inapropiados para expresar lo que Dios nos ha comunicado de sí mismo en Jesucristo y en su Espíritu para la salvación de la Humanidad.

Segunda. Todo discurso sobre Dios ha de tener como interlocutores a los sufrientes de la historia y ha de estar acompañado de los gritos de los miserables de la tierra. En esta interlocución se juega su contemporaneidad el lenguaje sobre Dios. Treinta años después vamos a recordar un texto de J. Moltnann que no ha perdido un ápice de actualidad: "La teología cristiana no puede asociarse al griterío de su propio mundo, aullando con los lobos dominantes. Pero sí que tiene que incorporarse al grito de los miserables hambrientos de Dios y libertad desde la profundidad de los sufrimientos de este tiempo. Como compañera de los sufrimientos de esta época, la teología cristiana es verdaderamente teología contemporánea. El que pueda serlo o no depende menos de la apertura al mundo de los teólogos y sus teorías, que de que sepa escuchar verdaderamente y sin componendas el grito de muerte de Jesús. Comparados con el grito del Jesús moribundo hacia Dios los esquemas teológicos caen pronto hechos pedazos por inadecuados. ¿Cómo puede una teología cristiana como tal hablar de Dios a la vista del abandono de Jesús por parte de aquél? ¿Cómo puede hacerlo una teología cristiana a la vista de Jesús gritando hacia Dios en la cruz?"z7.

Tercera. Todo discurso sobre Dios ha de ser consciente de su precariedad: "Todas las nuevas formas de hablar sobre Dios no son más que tanteos. Pero

25. Veáse J. y L. Marion, op. cit., pp. 15-38; puede verse el comentario de A. Torres Queiruga a las ideas de este autor, op. cit., p. 328; asi mismo J. Moingt, "Imágenes, iconos e ídolos de Dios", Concilium 289 (2001), pp. 154-156.

26. W. Kasper, EI problema de Dios en la predicación, en J. Ratzinger, Dios como problema, Madrid 1973, 217-218.

27. J. Moltmann, El Dios crucificado, Salamanca, 1975, pp. 218-219. 
aunque la teología consiguiese responder de un modo nuevo a las preguntas sobre Dios, ello volvería a ser otra vez meramente una respuesta provisional. Pues tan sólo el evangelio es eterno, en cambio la teología es temporal: ha de estar siempre traduciendo de nuevo el evangelio etemo para cada época cambiante. Por eso, la catedral que construyen los teólogos no estará nunca acabada, y no debe estar nunca acabada si es que realmente ha de ser una catedral en la que se predique y se ore a Dios... No debe ser colocada la clave de bóveda si el cielo ha de entrar dentro... Pero como no se puede colocar la clave que sostiene y mantiene la bóveda, ésta se viene continuamente abajo, la teología está constantemente condenada al fracaso. La teología fracasa por la grandeza de su objeto. A pesar de ello no podemos ni debemos renunciar a ella. Hemos de estar siempre empezando de nuevo a construir, osando de nuevo algo inaudito que consiste en que los hombres -hombres pecadores, finitos, imperfectos, mortalesse atreven a hablar de Dios con sus palabras. Aquí también es la gracia de Dios la única que puede enmendar lo que el hombre hace mal en cualquier caso. Dios tiene que perdonarnos también nuestra teologia, quizá más que nada nuestra teología"2s.

Cuarta. Como nos recuerda un lúcido texto de J. Martín Velasco, las pretensiones desmesuradas del discurso sobre Dios terminan por revestir de inhumanidad la teología:

Sucede cada vez que "dios", el nombre y el concepto elaborado por la razón del teólogo convertida en criterio de lo real, sustituye al Dios término de la adoración, la alabanza y la invocación del creyente. Tal "dios" crialura de la razón, con frecuencia so capa de "religiosidad", proyecta sobre el Dios de los creyentes los rasgos de una razón humana que se arroga el derecho de definición de la totalidad de lo real. El resultado es que tal comprensión de Dios pierda los rasgos de la proexistencia, la donación de sí, la humanidad del Dios que se revela a los sencillos, y que esta pérdida se traduzca en la inhumanidad de tal teología.

El teólogo termina por creer que está en lugar de Dios y que puede decir una palabra sobre $\mathrm{El}$ sin condicionamientos sociales y culturales:

Sucede a veces que, a fuerza de hablar sobre Dios, el teólogo cree que puede ponerse en su lugar, conocer su "naturaleza" y gozar de la visión de la realidad sub specie aetemitatis que procura tan privilegiada atalaya. Una atalaya que, naturalmente, queda fuera de los condicionamientos de tiempo y lugar, de lenguaje, grupo humano y cultura que son propios del conocimiento incurablemente finito de todos los humanos, y que le permitiría llegar a un saber ahistórico y transcultural sobre la realidad tal cual es en sí misma para

28. H. Zahmt, $A$ vueltas con Dios. La teología protestante en el siglo $\mathrm{XX}$, Zaragoza, 1972, p. 413. 
la mirada absoluta -libre de toda referencia y condicionamiento- de Dios... y del té́logo.

En boca de este tipo de teólogo Dios termina por ser inhumano y tiene la función de legitimar los privilegios de instituciones igualmente inhumanas que pretenden representarle:

Hagamos el pequeño ejercicio de imaginación que supone remitir a este teólogo a las disputas bien humanas sobre la naturaleza de las cosas, sobre la condición humana, sobre las circunstancias para su mejor realización en el mundo, sobre su futuro, sobre los problemas que le plantean los cambios históricos, sobre la interpretación de los hechos y los textos del pasado. ¿En cuántas de estas cuestiones dispondrá nuestro teólogo de un conocimiento sobre la naturaleza de las cosas, del hombre, de la historia, que le impedirán tomar en serio las preguntas de sus coetáneos y le impondrán el "sagrado deber" de decir una palabra autorizada que en otros tiempos ha supuesto un freno para la razón y todavía en el nuestro puede llevarle a atribuirse una autoridad que no es más que el producto de su ilusión?

El té́logo dotado de tales prerrogativas tiende a definir consiguientemente lo que él considera "los derechos de Dios" y a erigirse en su esforzado defensor. El resultado de esta usurpación del lugar de Dios por el teólogo es, con frecuencia, que el Dios de las tradiciones religiosas, que se distinguía por hacer suyos los derechos de los pobres, de los que no tenían derechos reconocidos, se convierta en manos de tales téblogos en un Dios que impone obligaciones y normas pesadísimas a las personas, y que parece hecho a la medida para garantizar los derechos y los privilegios de las instituciones que dicen representarle en la sociedad ${ }^{29}$.

Las notificaciones de la Congregación para la Doctrina de la Fe o de la Comisión Episcopal para la Doctrina de la Fe acerca de la ortodoxia del discurso de los teólogos me parecen un claro ejemplo -y lo digo con dolor- de una manera inhumana de hablar de Dios. Algunos casos, como el de M. Vidal y el J. J. Tamayo en la comunidad teológica española, han puesto de manifiesto que los procedimientos seguidos para valorar la ortodoxia de sus discursos son un abuso de poder espiritual ${ }^{30}$, que oculta la humanidad de Dios y sus entrañas de misericordia. La iglesia antigua buscó la ortodoxia del lenguaje sobre Dios movida por un interés: proteger la verdad del acontecimiento salvífico acontecido en Jesucristo y su Espíritu en aquel esfuerzo colosal por inculturar el Evangelio en el

29. J. M. Velasco, "La humanidad de Dios y la del télogo", en Revista Catalana de Teología XXV (2000), La Humanitat a la recerca de Déu, pp. 412-413.

30. Véase J. Perea González, "Un abuso de poder espiritual. 'Notificación sobre los escritos del Rvdo. P. marciano Vidal, C.Ss.R'", Iglesia Viva 206 (2001), pp. 125131. 
mundo cultural grecolatino que ella realizaba y para el que en principio no contaba con delimitación doctrinal alguna. Hoy muchos tenemos la impresión de que los procesos seguidos por estas instituciones jerárquicas buscan más defender la verdad de una doctrina o de un catecismo que esclarecer la verdad del Evangelio de Dios para los hombres y mujeres del siglo XXI. La sistemática sustitución de un procedimiento de discernimiento de la verdad que garantice los derechos legales de los encausados por otro, propio del antiguo régimen y de su concepción absolutista del poder, que no los respeta ${ }^{31}$, y la apelación como justificación a la calidad sobrenatural, sagrada o divina del poder magisterial, hace que su discurso incurra en una especie de "monofisismo neumatológico" paralelo al monofisismo cristológico condenado por la Iglesia, es decir, en una concepción de la presencia y la acción de Dios que se da suprimiendo y suplantando la condición humana ${ }^{32}$.

A menudo pienso que dichas instituciones caen en un error análogo al cometido por S. Atanasio en su defensa de la ortodoxia. Su ardor por defender la consustancialidad divina de Jesús frente a Amio no le permitió caer en cuenta que compartía el mismo error arriano sobre la humanidad de Jesús. Y así negaba su verdadera humanidad: su carne animada por el Logos carecía de alma. De manera semejante se defiende vehementemente el carácter "sobrenatural" de la práclica seguida para examinar los escritos de cualquier autor cuya doctrina parezca "errónea" o "peligrosa" y se olvida que su "consustancialidad" con las práclicas humanas reclama la inspiración de principios humanos verdaderos. Y esto no será posible mientras se desconozcan sistemáticamente los métodos y normas -como, por ejemplo, los derechos procesales y el diálogo con el encausado, etc.- que los seres humanos nos hemos dado razonablemente a nosotros mismos para evitar actuaciones injustas de la autoridad y humanizar las relaciones con el poder. El resultado es algo mucho más grave que la doctrina errónea que se condena. Se trata de un discurso inhumano sobre Dios.

Quinta. Una vez que el cristianismo ha dejado de ejercer como religión política del aniguo régimen y la Iglesia ha quedado situada en la periferia del foro público como consecuencia de los cambios políticos y culturales -algo que en el caso español ha ocurrido, en tiempos todavía muy recientes-, se ha de proceder a cambiar el talante del discurso público sobre Dios. El acento ha de desplazarse del contundente anuncio social, fundado sobre el consenso mayoritario de la muchedumbre y el rechazo de todo desvío como antisocial, a la oferta más discreta de una palabra, ligada a una práctica comunitaria, que busca la conversión, a través del diálogo y la escucha.

31. Véase J. M² Mardones, El Magisterio como poder, en AA. VV., Teología y Magisterio, Salamanca 1987, pp. 174-177.

32. Véase J. I. González Faus, La autoridad de la verdad, Barcelona 1996, p. 185. 
Vivimos tiempos en los cuales la respuesta eclesial al mandato del Señor de evangelizar a todas las naciones (cfr. Mi 28,19 ) pasa por la búsqueda de modos más humildes de anuncio del nombre de Dios, que hagan posible que su presencia gratuita en la historia humana se convierta en experiencia humana y humanizadora de encuentro con El. La insistencia en un anuncio más contundente de Dios parece que busca más el patrocinio en exclusiva de Dios para la Iglesia que testificar su nombre. El uso más frecuente que el lenguaje eclesiástico hace del nombre de Dios, vinculándolo casi exclusivamente a una moral seca y dura, corre el riesgo de distorsionar la imagen del Dios de vida, cuya moral es, a la vez, radicalmente exigente y graciosamente misericordiosa.

Sexıa. Nuestro lenguaje sobre Dios ha de ser consciente de que las categorías son siempre más pobres que los acontecimientos y ha de redescubrir la capacidad que los relatos tienen para hacer revivir en nosotros las peripecias de la realidad, de mantener vivos los acontecimientos, en la medida en que las historias que se cuentan se perciben como historia propia.

En general, la teología europea, siento tener que insistir una vez más en ello, es superdocta, en relación con los textos escritos, pero muestra una ignorancia supina acerca de aquellos relatos humanos -argumentos en forma de vida-, que impiden prácticamente cualquier lectura reductora y acomodaticia del evangelio de la salvación de Dios. Generalmente, cuando se nos presenta en los foros públicos a los teólogos, se proclaman nuestros méritos, que suelen consistir en titulaciones, rangos académicos y publicaciones más notables. Rara vez se miden nuestros respectivos curriculum virae por la valla de nuestras experiencias humanas y cristianas, ni por la calidad de nuestra solidaridad compartida con los pobres. ¿Estaremos los té́logos europeos incapacitados para salvar ese profundo cisma entre sistema teológico y experiencia religiosa, entre doxografia y biografía, entre dogmática y mística, que -como se ha denunciado- parece caracterizar nuestros discursos? 